\title{
A REVIEW OF WILD AND SYNANTROPIC BIRDS RECORDED AS RESERVOIRS OF AVIAN INFLUENZA VIRUSES IN BULGARIA
}

\author{
S. NIKOLOV ${ }^{1}$, M. H. MARINOVA ${ }^{2}$, B. MURAD ${ }^{1} \&$ I. TSACHEV $^{1}$ \\ 1Faculty of Veterinary Medicine, Trakia University, Stara Zagora, Bulgaria; \\ 2Department of Biology and Aquaculture, Faculty of Agriculture, \\ Trakia University, Stara Zagora, Bulgaria
}

\section{Summary}

Nikolov, S., M. H. Marinova, B. Murad \& I. Tsachev, 2020. A review of wild and synantropic birds recorded as reservoirs of avian influenza viruses in Bulgaria. Bulg. J. Vet. Med., 23, No 3, 271-284.

The aim of the present review is to summarise the information about the species diversity of wild and synanthropic birds, which have been recorded as reservoirs of influenza in Bulgaria until 2018. A total of 17 species of wild and synantropic birds were reported. They belong to 16 genera, 11 families and 10 orders of the class Aves. A list of wild and synantropic birds - potential reservoirs of influenza in Bulgaria is also presented.

Key words: Bulgaria, influenza, wild birds, synantropic birds

\section{AVIAN INFLUENZA}

The avian influenza is an acute viral infection in birds, causing serious economic loss all over the world. The viruses belong to the family Orthomyxoviridae, genus Influenza. There are three genera - A, B and C. Only influenza A viruses are known to infect birds. The genome is single-stranded, segmented (-) RNA with 8 structural proteins. The more important proteins are haemagglutinin $(\mathrm{H})$ and neuraminidase $(\mathrm{N})$. At present, $16 \mathrm{H}$ subtypes (H1-H16) and $9 \mathrm{~N}$ subtypes (N1N9) are recognised. On the basis of their haemagglutinin and neuraminidase anti- gens viruses are classified into subtypes. A further classification into phenotypes of low and high pathogenicity (LP/HP) refers to their virulence in chickens. The genetic variability in influenza viruses is due to two phenomena: antigenic shift - sharply changing structures in the genome (resortation) and antigenic drift - spotted mutations in the genome, which occur rarely (OIE, 2015; Graaf et al., 2018).

The importance and prevalence of disease is due to its fast spread via wild and synantropic bird species. Waterfowl and seabirds provide a vast global reservoir 
for influenza A viruses of all haemagglutinin and neuraminidase subtypes. In these birds, influenza viruses infect epithelial cells of the gastrointestinal tract, but generally do not produce clinical signs of illness. A natural reservoir of the virus are waterfowl birds from the following orders: Anseriformes (mainly ducks, geese and swans), Charadriiformes (mainly gulls, terns and waders), Procellariifor-mes, Pelecaniformes, Gruiformes, Phoenicopteriformes, Ciconiiformes, Podicipediformes and Gaviiformes (Stallknecht \& Shane, 1988; Webster et al., 1992; Alexander, 2000; Olsen et al., 2006; Kim et al., 2009; Van Dijk et al., 2013; Verhagen, 2016; FAO, 2007). They are natural hosts of low pathogenic strains (LPAIV) and are permanent transmitters of the virus. However, the genetically unstable genomic structure often changes in highly pathogenic strains that affect poultry.

On the other hand, an important role in the spread of influenza play synantropic birds from orders Passeriformes, Falconiformes, Strigiformes, Columbiformes and others as they are in direct contact with domestic poultry (Magnino et al., 2000; Desvaux et al., 2009; Kaplan \& Webby, 2013; EFSA et al., 2017b). They mediate the relationship with wild migrating species, often only as mechanical vectors. Some of species listed below are conditionally mentioned as synantropic as their habitats are both in urban and nonurban territories.

\section{AVIAN INFLUENZA IN BULGARIA}

The global spread of avian influenza in Bulgaria is supported by the two migration routes of birds, namely Via Pontica and Via Aristotelis. Habitats for feeding and breeding are also important for the transmission of the virus. Last but not least, the anthropological factor, transpor- tation and trade with domestic and exotic bird species should be emphasised.

The present study summarises all data on wild and synantropic bird species recorded as influenza reservoirs in Bulgaria. The avian species are arranged by the classification adopted by the Fauna Europaea database. The nomenclature of the birds follows Roselaar (2004).

Detailed studies on the prevalence of influenza A in birds in Bulgaria are reported by Zarkov et al. (2006), Goujgoulova \& Oreshkova (2007), Zarkov (2008), Georgiev et al. (2009), Goujgoulova et al. (2010), Marinova-Petkova et al. (2012; 2016), Stoimenov (2016), Stoimenov et al. (2017a,b). Summarised data for Bulgarian bird species in which influenza $\mathrm{A}$ was detected, habitats, the period of collection of samples, sample type, detected AIV strains are shown in Table 1.

Zarkov et al. (2006) were the first to discover an avian influenza virus (AIV) isolate in Bulgaria. During two autumnwinter seasons (from December 6, 2003 to March 3, 2004 and from December 13, 2004 to March 3, 2005), 236 faecal, cloacal, intestinal and visceral samples were collected from migrating waterfowl spending the winter in Bulgaria. The authors isolated a viral agent that was identified as AIV virus subtype H6N2 (LPAI) and originated from a bird sampled around Lake Vaya, Burgas.

In their study on avian influenza in Bulgaria, Goujgoulova \& Oreshkova (2007) outlined as the most notable result the occurrence of a highly pathogenic influenza virus (H5N1). The isolates were from four dead swans of the Cygnus olor species from four water areas (Table 1). In addition, the authors also isolate two influenza viruses, which are not from the H5N1 subtype. The first virus was H4, 


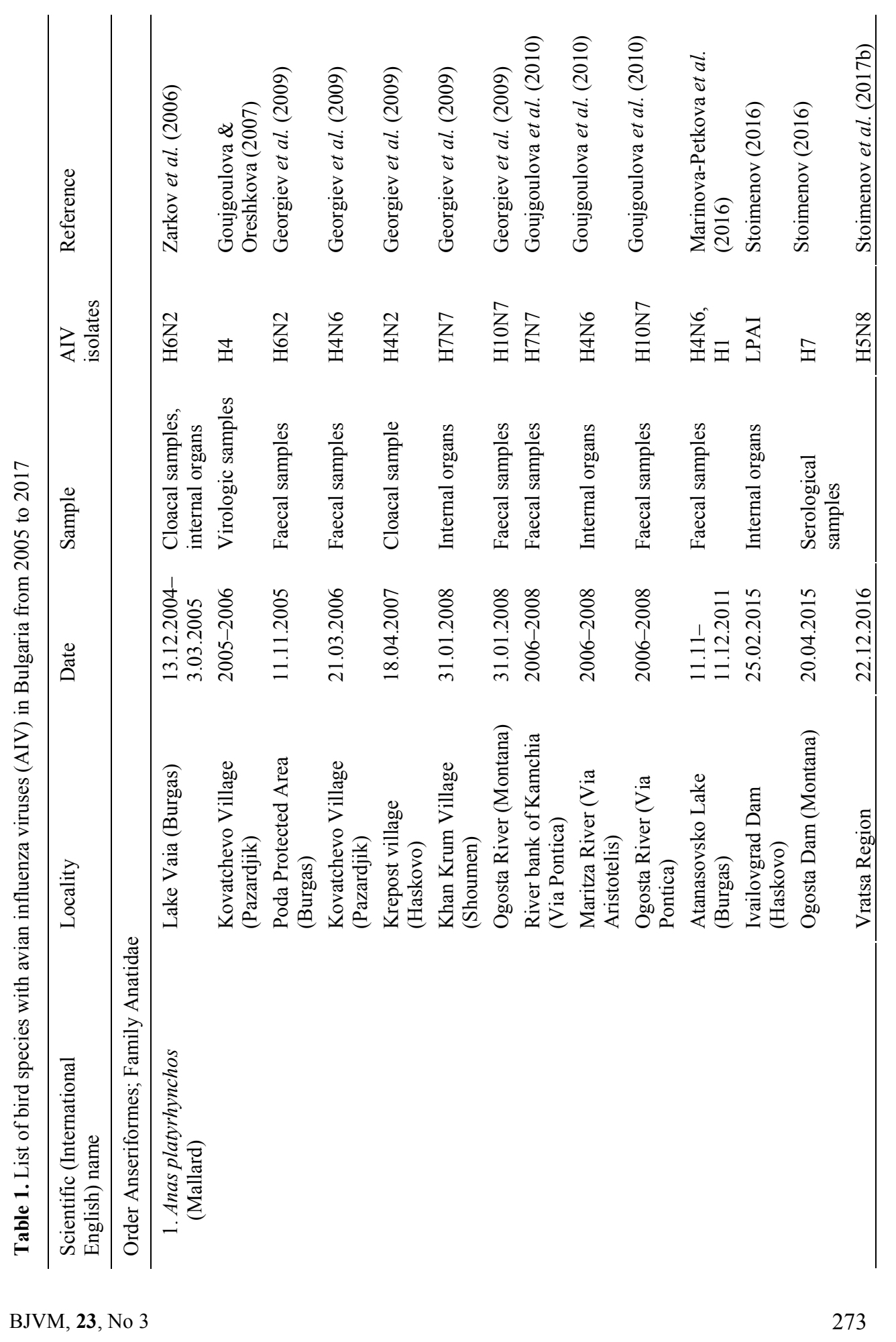


A review of wild and synantropic birds recorded as reservoirs of avian influenza viruses in Bulgaria

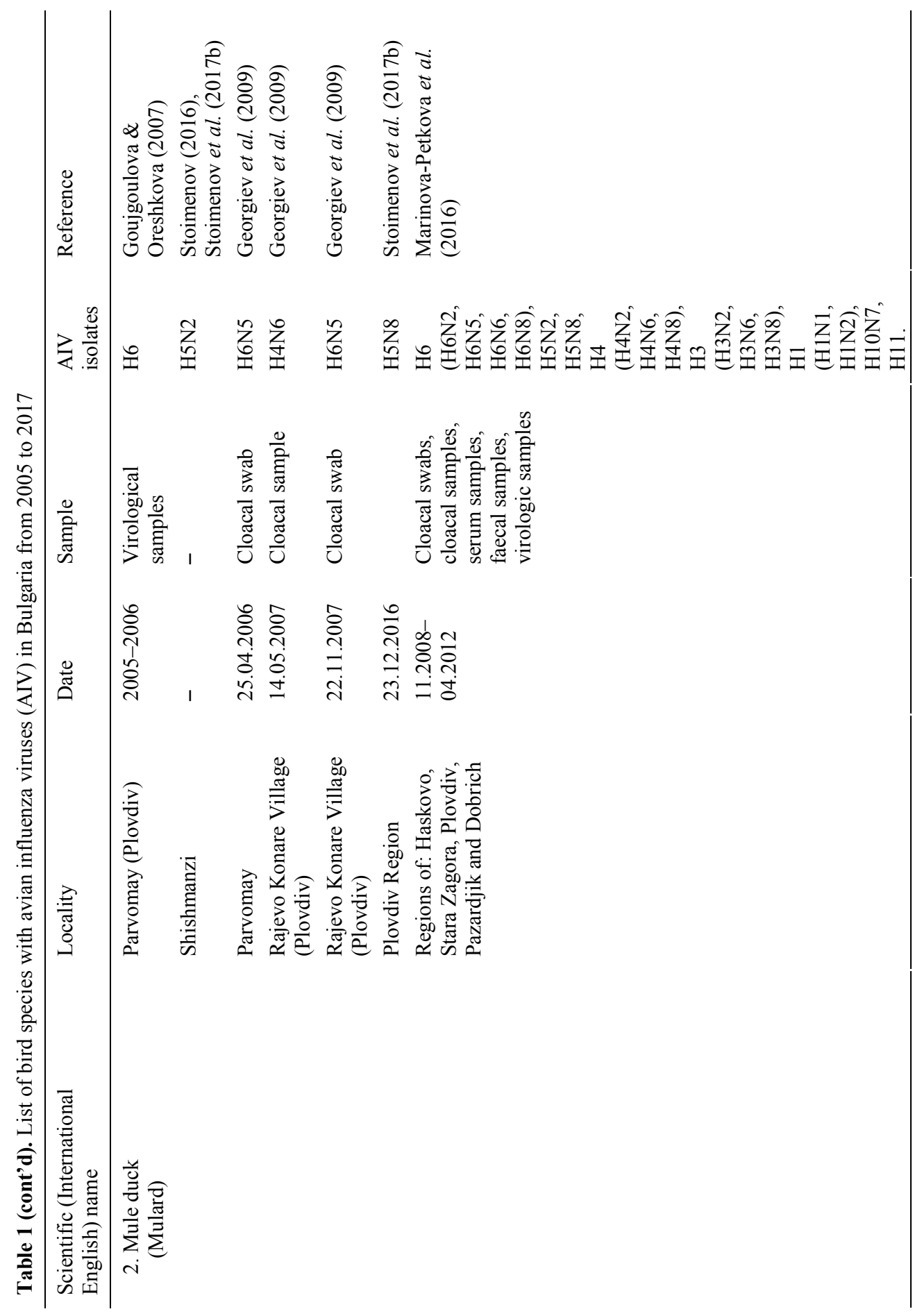




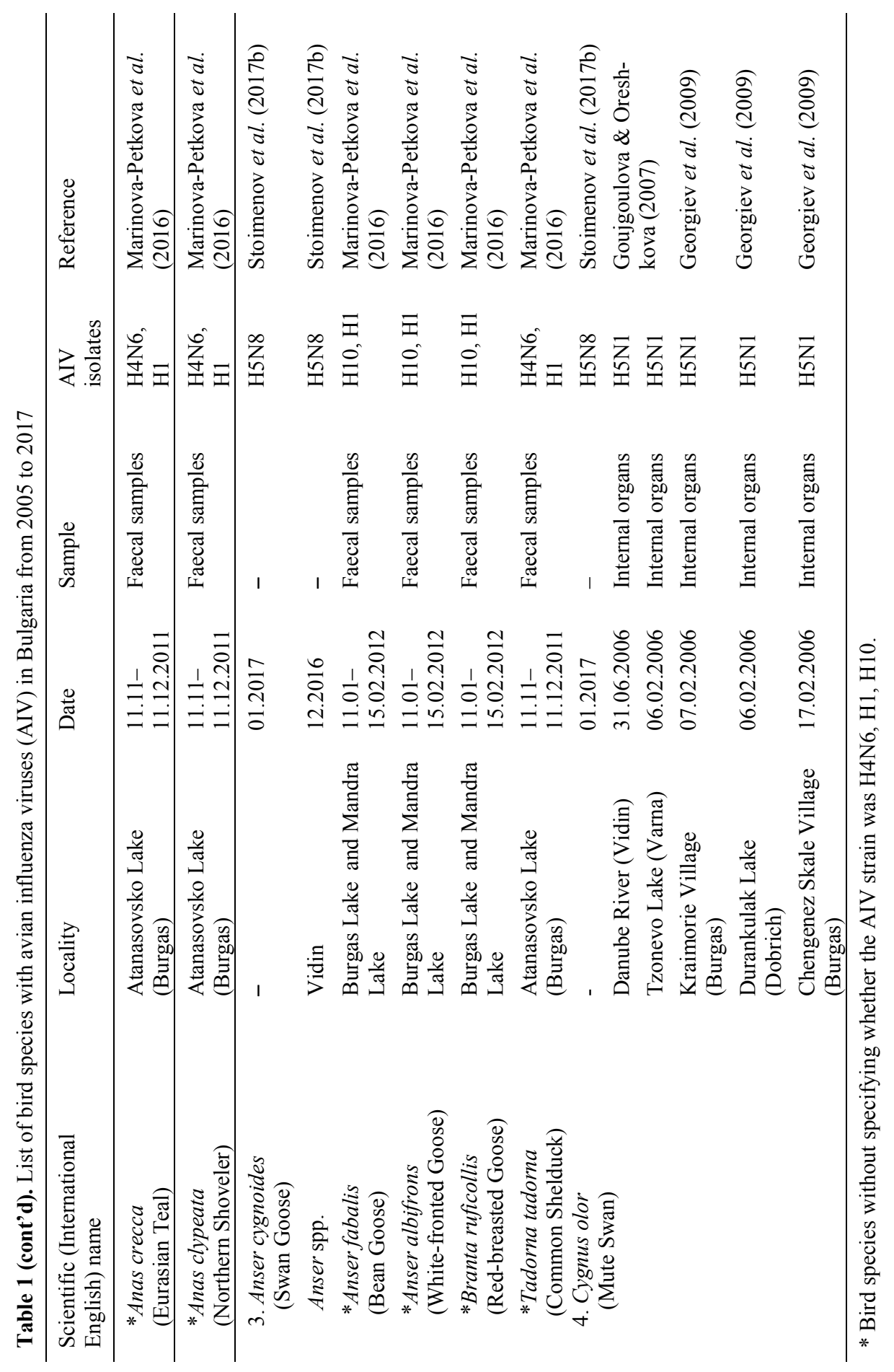

BJVM, 23, No 3 


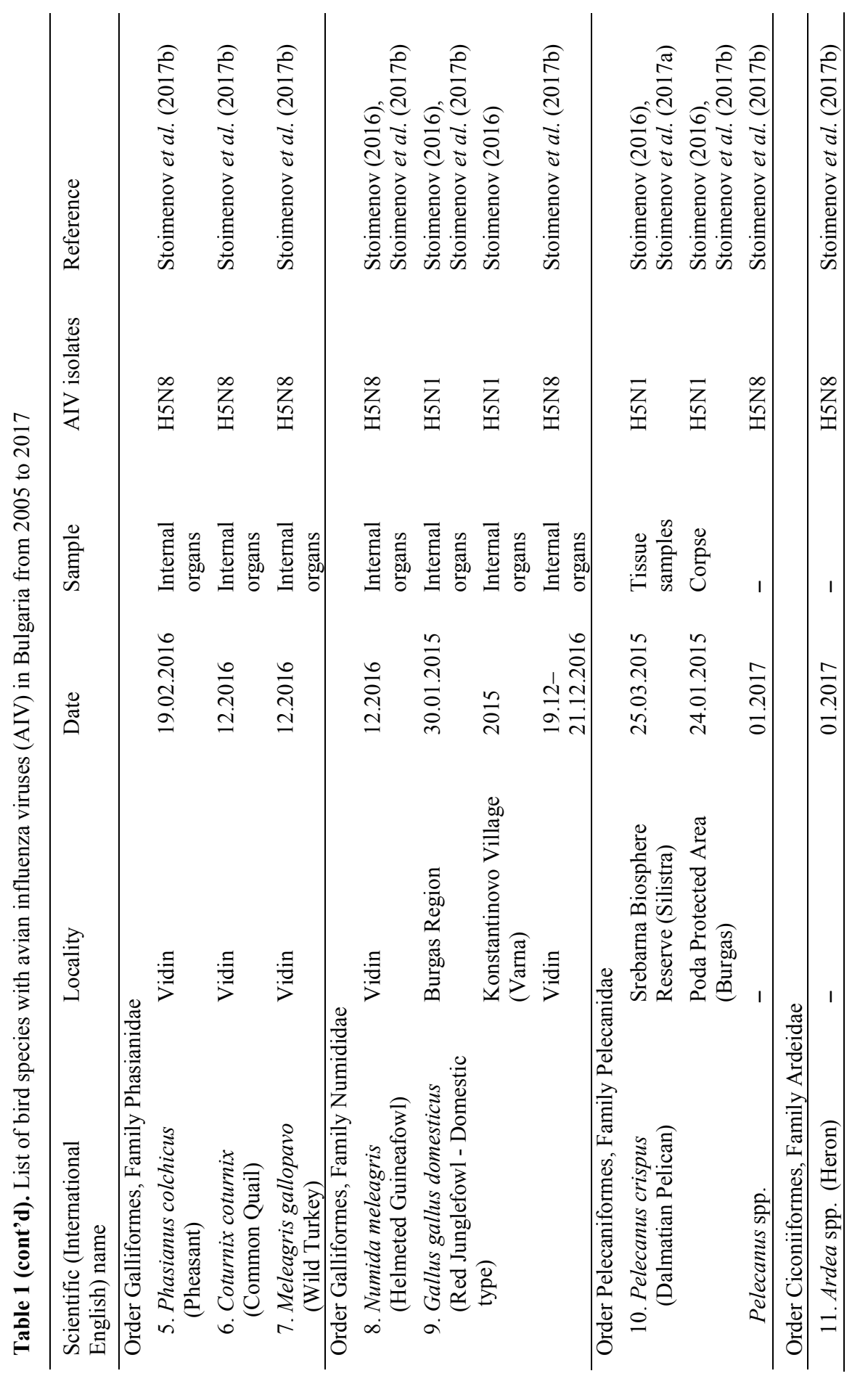




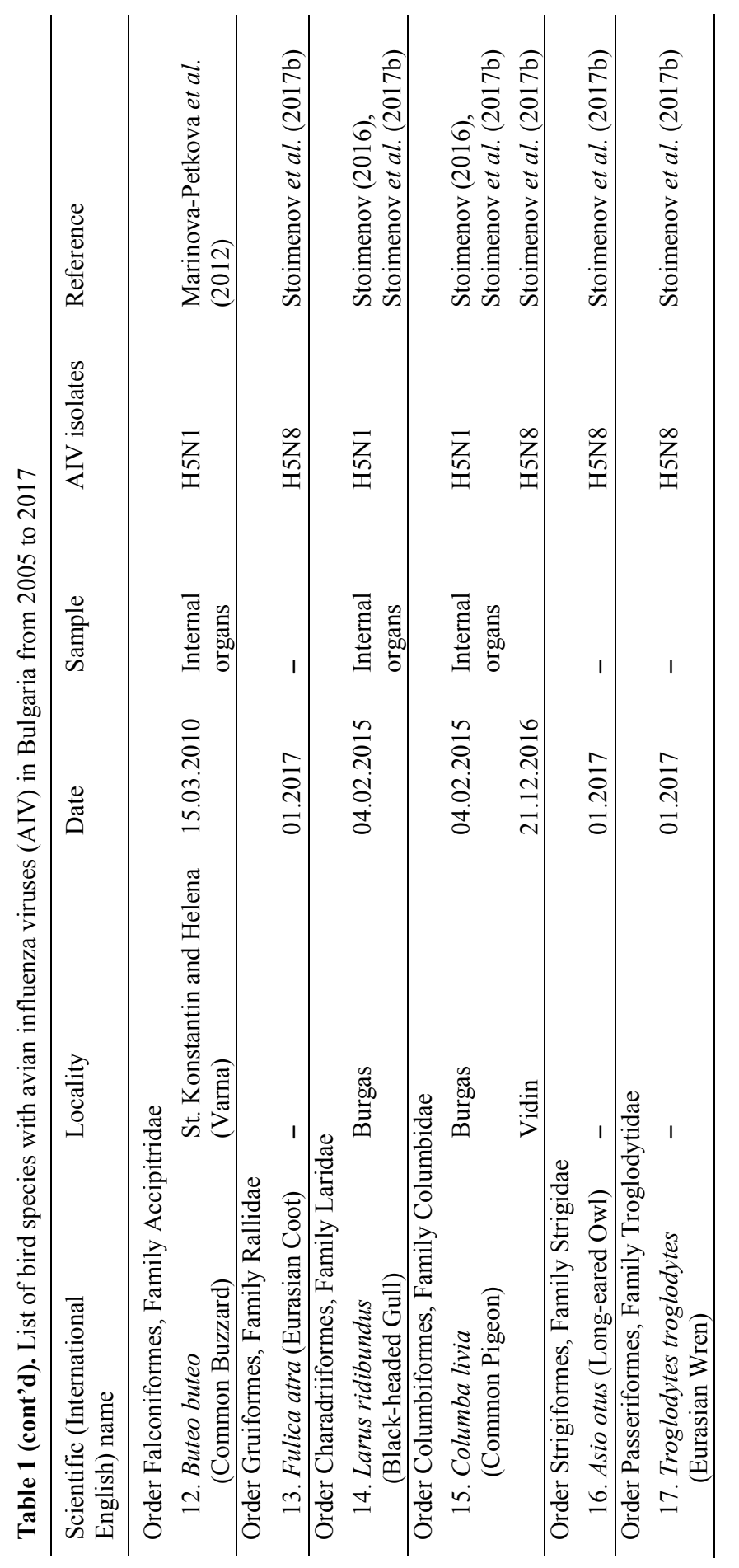

BJVM, 23, No 3 
isolated from $A$. platyrhynchos reared for hunt in an area called Korijata near the village of Kovachevo, Pazardjik Region. The second virus was H6, from ducklings imported from France and reared in a farm in the city of Parvomay, Plovdiv region (Goujgoulova \& Oreshkova, 2007). The authors indicated that all influenza isolates obtained so far were from wild birds.

Georgiev et al. (2009) published data for the current status, surveillance and control of avian flu in domestic and wild bird populations in Bulgaria. For the period 2005-2008, 8 AIV subtypes were isolated from Anatidae spp. in Bulgaria (Table 1). Based on risk analysis, the authors affirmed that future research studies should focus on the populations of several wild migratory ducks species, wintering at Shabla Lake (district of Dobrich), Beloslav Lake (district of Varna) and the wetlands Poda connected with Mandra Lake (district of Burgas).

Subsequently, Goujgoulova et al. (2010) examined more than 2000 samples from wild birds in Bulgaria from the orders Anseriformes, Ciconiformes, Gruiformes and Charadriformes in the period 2006-2008. Three influenza viruses (subtypes H4N6, H7N7 and H10N7) were isolated, all from Anas platyrhynchos, from three water areas (Table 1). All these viruses were detected during the active migration of the birds in February and March.

Marinova-Petkova et al. (2012) published data from the continuous monitoring of the bird areas along the Black Sea coast, near the Danube River and around the Ogosta Dam and Lom River. A total of 812 cloacal, faecal, and tissue samples from wild birds collected from these areas were tested for avian influenza virus for the period 1 January 2010 - 30 April 2010; 269 samples were collected after
March 15, 2010. All tested samples were negative for HPAIV (H5N1). At the same time, the authors reported about five carcasses of common buzzards found in different areas, examined in the Regional Diagnostic Lab on Avian Influenza after March 15, 2010. One of them was carrying HPAIV (H5N1). This is the first record of HPAIV (H5N1) from common buzzard (Buteo buteo) in Bulgaria (Table 1).

Marinova-Petkova et al. (2016) conducted a study aimed at clarification of the role of 'foie gras' ducks in the circulation of AIVs in Bulgaria. The study included Influenza surveillance of 63 'foie gras' duck farms in Bulgaria for the period 2008-2012. The study showed high isolation frequency of low-pathogenicity avian influenza viruses. At the same time the authors collected wild bird samples at major wild bird-resting areas near the Black Sea coast and Danube River (Table 1) however, they did not specify the avian species from which AIV H4N6, H1 and H10 were isolated (Marinova-Petkova et al., 2016). The same study noted that wild bird surveillance showed low isolation frequency of AIV: prevalence of $0.55 \%$ for migratory ducks and $0.53 \%$ for migratory geese was estimated in November-December 2011 and JanuaryFebruary 2012, respectively, at two ornithologically important locations near the Black Sea coast.

Stoimenov (2016) performed a largescale investigation on influenza $\mathrm{A}$ viruses in Bulgaria over a 2-year period (20142016). Samples were collected from different wild bird species from areas at high risk for avian influenza $\mathrm{A}$ in order to detect the prevalence of the virus. The work comprised 49 bird species among which 17 waterfowl species, 16 migratory, 9 exotic and 17 resident for Bulgaria, including predatory birds. 
Stoimenov (2016) isolated for the first time in Bulgaria AIV by classical methods for diagnostics of H5N1 subtypes from Dalmatian pelicans (Pelicanus crispus) living in two epidemiological foci in 2015. During the same enzooty, another two HPAI H5N1 strains were detected in 2 synanthropic bird species: black-headed gull (A/Larus ridibundus/Burgas/Bulgaria/2015) and rock dove (A/Columbia livia/Burgas/ Bulgaria/2015) as well as 1 LPAI strain from Anas platyrhynchos.

Stoimenov et al. (2017a) published a study on the histopathological changes in visceral organs of naturally infected with the avian influenza virus (AIV) subtype A $\mathrm{H} 5 \mathrm{~N} 1$ dalmatian pelicans in Bulgaria (Table 1). The virus was detected by virus isolation (VI) and RT-PCR from tissue samples (lung, trachea, small intestine, brain, proventriculus, cloaca) from the infected birds.

Stoimenov et al. (2017b) summarised the data on distribution, biological and epizootiological features of highly pathogenic avian influenza of subtype H5N8 in Europe and Bulgaria in 2016/2017. For this period, a total of 87 species of affected wild birds were found out in Europe, including migratory waterfowl and local predatory and synanthropic species. Eighty-eight percent of identified bird species belonged to the list of of species target for the disease and thus, of priority for HPAI surveillance in the EU. Main infected species out of the EU HPAI $\mathrm{H} 5 \mathrm{~N} 1$ target species list outlined in this study are Larus argentatus (3\%) and Larus marinus (1\%).

AIV serotype H5N8 was first encountered in Bulgaria on 19 December 2016 in chickens, pheasants and guinea fowl (Stoimenov et al., 2017b). Until 16 January 2017, more than 60 influenza outbreaks in domestic birds and more than 10 cases in wild birds were confirmed. Fortyfour duck's farms and one for laying hens were affected. The analysis of epidemiological data showed that chickens, turkeys and guinea fowl were the most susceptible to the virus, while mallards were asymptomatic carriers and vectors of infection.

Table 2 presents a list of Bulgarian bird species that could be treated as potential AIV reservoirs in the country on the basis of available literature reports for the species of which they are isolated (Stallknecht \& Shane, 1988; Kwon et al., 2005; Olsen et al., 2006, Munster et al., 2007; Teifke et al., 2007; Gaidet et al., 2012; Stallknecht \& Brown, 2016; Verhagen, 2016; Stoimenov et al., 2017b; EFSA et al., 2017a,b; 2018).

\section{CONCLUSION}

According to Olsen et al. (2006) naturally occurring infections with AIV have been reported in free-living birds from 26 families, representing 105 species. Data from previous studies on avian influenza in Bulgaria demonstrated that the number of avian species positive for AIV was far lower than that reported at a global scale. It should be noted that performed studies with highest number of experimental subjects included predominantly birds inhabiting water areas, as well as domestic birds. Purposeful future studies are needed to expand the species composition of tested birds (for example from the orders Passeriformes and Strigiformes) as well as tests on more individuals from every species. This would undoubtedly broaden the host range of avian influenza virus among free-living birds in Bulgaria.

On the basis of available literature reports, it could be summed up that at present, 17 avian species belonging to 16 
A review of wild and synantropic birds recorded as reservoirs of avian influenza viruses in Bulgaria

Table 2. List of wild and synantropic birds - potential reservoirs of AIV in Bulgaria

\begin{tabular}{|c|c|}
\hline \multicolumn{2}{|l|}{ Order Anseriformes } \\
\hline $\begin{array}{l}\text { Family Anatidae } \\
\text { Subfamily Anserinae }\end{array}$ & $\begin{array}{l}\text { Anser anser, Anser erythropus, Anser caerulescens, Anser } \\
\text { brachyrhynchus, Branta canadensis, Branta leucopsis, } \\
\text { Branta bernicla, Cygnus cygnus, Cygnus columbianus, } \\
\text { Cygnus bewickii, Cygnus atratus }\end{array}$ \\
\hline Subfamily Anatinae & $\begin{array}{l}\text { Tadorna ferruginea, Anas strepera, Anas falcata, Anas penelope, } \\
\text { Anas acuta, Anas querquedula, Bucephala clangula, } \\
\text { Aythya ferina, Aythya nyroca, Aythya fuligula, Aythya } \\
\text { marila, Netta rufina, Clangula hyemalis, Somateria mollissima, } \\
\text { Melanitta fusca, Melanitta nigra, Aix sponsa, Mergus serrator, } \\
\text { Mergus merganser, Mergellus albellus }\end{array}$ \\
\hline \multicolumn{2}{|l|}{ Order Charadriiformes } \\
\hline Family Scolopacidae & $\begin{array}{l}\text { Arenaria interpres, Calidris temminckii, Calidris alpina, } \\
\text { Calidris alba, Calidris canutus, Scolopax rusticola, Tringa } \\
\text { erythropus, Tringa totanus, Tringa glareola, Tringa ochropus, } \\
\text { Philomachus pugnax, Numenius arquata }\end{array}$ \\
\hline Family Charadridae & Vanellus spinosus, Charadrius dubius \\
\hline Family Laridae & $\begin{array}{l}\text { Larus atricilla, Larus fuscus, Larus marinus, Larus genei, } \\
\text { Larus argentatus, Larus canus, Larus delawarensis, Larus hy- } \\
\text { perboreus, Larus melanocephalus, Larus michahellis, } \\
\text { Larus sabini, Rissa tridactyla, Sterna hirundo, Sterna para- } \\
\text { disaea, Sterna sandvicensis, Chlidonias niger, } \\
\text { Chlidonias hybridus, Chlidonias leucopterus }\end{array}$ \\
\hline Family Alcidae & Uria aalge \\
\hline \multicolumn{2}{|l|}{ Order Pelecaniformes } \\
\hline Family Pelecanidae & Pelecanus onocrotalus \\
\hline Family Phalacrocoracidae & Phalacrocorax carbo \\
\hline \multicolumn{2}{|l|}{ Order Gruiformes } \\
\hline Family Rallidae & Gallinula chloropus, Rallus aquaticus \\
\hline \multicolumn{2}{|l|}{ Order Ciconiformes } \\
\hline Family Ciconidae & Ciconia ciconia \\
\hline Family Ardeidae & $\begin{array}{l}\text { Ardea alba, Ardea cinerea, Ardeola ralloides, Botaurus stellaris, } \\
\text { Egretta garzetta }\end{array}$ \\
\hline Family Threskiornithidae & Plegadis falcinellus \\
\hline \multicolumn{2}{|l|}{ Order Podicepediformes } \\
\hline Family Podicipedidae & $\begin{array}{l}\text { Podiceps cristatus, Podiceps grisegena, Tachybaptus ruficollis, } \\
\text { Podiceps nigricollis }\end{array}$ \\
\hline \multicolumn{2}{|l|}{ Order Gaviiformes } \\
\hline Family Gaviidae & Gavia arctica, Gavia stellata \\
\hline
\end{tabular}


Table 2 (cont'd). List of wild and synantropic birds - potential reservoirs of AIV in Bulgaria

\begin{tabular}{ll}
\hline Order Galliformes & \\
Family Phasianidae & Alectoris graeca, Coturnix coturnix \\
\hline Order Passeriformes & \\
Family Passeridae & Passer domesticus \\
Family Hirundinidae & Hirundo rustica \\
Family Emberizidae & Emberiza schoeniclus \\
Family Muscicapidae & Ficedula hypoleuca, Muscicapa striata \\
Family Corvidae & Pica pica, Corvus monedula, Corvus frugilegus, Corvus cornix, \\
& Corvus corax \\
Family Saxicolidae & Phoenicurus phoenicurus \\
Family Turdidae & Turdus merula, Turdus philomelos, Turdus pilaris \\
Family Sturnidae & Sturnus vulgaris \\
Family Sylviidae & Sylvia communis, Sylvia borin, Hippolais icterina, \\
Family Muscicapidae & Phylloscopus trochilus \\
Family Motacillidae & Muscicapa striata \\
Family Laniidae & Motacilla flava \\
\hline Order Piciformes & Lanius collurio \\
\hline Order Falconiformes & Dendrocopos major \\
Family Falconidae & Falco tinnunculus, Falco peregrinus, Falco cherrug \\
Family Accipitridae & Buteo lagopus, Aquila spp., Accipiter nisus, Accipiter gentilis, \\
\hline Order Strigiformes & Haliaeetus albicilla \\
Family Strigidae & Bubo bubo, Strix aluco \\
Family Tytonidae & Streptopelia decaocto, Columba palumbus \\
\hline Order Columbiformes & \\
\hline Family Columbidae & \\
\hline
\end{tabular}

genera, 11 families and 10 orders were established as AIV reservoirs in Bulgaria. Other possible reservoirs could be found among at least 119 bird species from 31 families and 14 orders, as already reported in the literature.

\section{REFERENCES}

Alexander, D. J., 2000. A review of avian influenza in different bird species. Veterinary Microbiology, 74, 3-13.

Desvaux, S., N. Marx, S. Ong, N. Gaidet, M. Hunt, J. C. Manguerra, S. Sorn, M. Peiris, S. Van der Werf \& J. M. Reynes, 2009. Highly pathogenic avian influenza virus (H5N1) outbreak in captive wild birds and 
cats, Cambodia. Emerging Infectious Diseases, 15, 475-478.

EFSA (European Food Safety Authority), ECDC (European Centre for Disease Prevention and Control), EURL (European Union Reference Laboratory for Avian Influenza), I. Brown, P. Mulatti, K. Smietanka, C. Staubach, P. Willeberg, C. Adlhoch, D. Candiani, C. Fabris, G. Zancanaro, J. Morgado \& F. Verdonck, 2017a. Scientific report on the avian influenza overview October 2016-August 2017. EFSA Journal, 15, 5018.

EFSA (European Food Safety Authority), ECDC (European Centre for Disease Prevention and Control), EURL (European Union Reference Laboratory for Avian Influenza), I. Brown, T. Kuiken, P. Mulatti, K. Smietanka, C. Staubach, D. Stroud, O. R. Therkildsen, P. Willeberg, F. Baldinelli, F. Verdonck \& C. Adlhoch, 2017b. Scientific Report: Avian influenza overview September-November 2017. EFSA Journal, 15, 5141.

EFSA (European Food Safety Authority), ECDC (European Centre for Disease Prevention and Control), EURL (European Reference Laboratory for Avian Influenza), C. Adlhoch, A. Brouwer, T. Kuiken, P. Mulatti, K. Smietanka, C. Staubach, P. Willeberg, F. Barrucci, F. Verdonck, L. Amato \& F. Baldinelli, 2018. Scientific report: Avian influenza overview November 2017-February 2018. EFSA Journal, 16, 5240 .

FAO, 2007. Wild Birds and Avian Influenza: An Introduction to Applied Field Research and Disease Sampling Techniques, eds D. Whitworth, S. H. Newman, T. Mundkur \& P. Harris. FAO Animal Production and Health Manual, No. 5, Rome.

Gaidet, N., A. B. Ould El Mamy, J. Cappelle, A. Caron, G. S. Cumming, V. Grosbois, P. Gil, S. Hammoumi, R. S. de Almeida, S. R. Fereidouni, G. Cattoli, C. Abolnik, J. Mundava, B. Fofana, M. Ndlovu, Y. Diawara, R. Hurtado, S. H. Newman, T. Dodman \& G. Balança. 2012. Investigating avian influenza infection hotspots in
Old-World shorebirds. PLOS ONE, 7, e46049.

Georgiev, G., G. Gujgulova, L. Polihronova, A. Teneva, I. Dimitrova, K. Ivanova \& E. Todorovska, 2009. Current status, surveillance and control of avian flu in domestic and wild bird populations in Bulgaria. In: Proceedings from FAO/IAEA International symposium on sustainable improvement of animal production and health, Vienna (Austria), 8-11 June, pp. 376-378.

Goujgoulova, G. \& N. Oreshkova, 2007. Surveillance on avian influenza in Bulgaria. Avian Diseases, 51, 382-386.

Goujgoulova, G., A. Marinova-Petkova \& G. Georgiev, 2010. Avian influenza viruses isolated from mallards in Bulgaria. Avian Diseases, 54, 450- 52.

Graaf, A., R. Ulrich, P. Maksimov, D. Scheibner, S. Koethe, E. M. Abdelwhab \& T. Harder. 2018. A viral race for primacy: Co-infection of a natural pair of low and highly pathogenic H7N7 avian influenza viruses in chickens and embryonated chicken eggs. Emerging Microbes \& Infections, 7, 204.

Kaplan, B. S. \& R. J. Webby, 2013. The avian and mammalian host range of highly pathogenic avian $\mathrm{H} 5 \mathrm{~N} 1$ influenza. Virus Research, 178, 3-11.

Kim, J. K., N. J. Negovetich, H. L. Forrest \& R. G. Webster, 2009. Ducks: the "Trojan horses" of H5N1 influenza. Influenza and Other Respiratory Viruses, 3, 121-128.

Kwon, Y. K., S. J. Joh, M. C. Kim, Y. J. Lee, J. G. Choi, E. K. Lee, S. H. Wee, H. W. Sung, J. H. Kwon, M. I. Kang \& J. H. Kim, 2005. Highly pathogenic avian influenza in magpies (Pica pica sericea) in South Korea. Journal of Wildlife Diseases, 41, 618-623.

Magnino, S., M. Fabbi, A. Moreno, G. Sala, A. Lavazza, E. Ghelfi, L. Gandolfi, G. Pirovano \& E. Gasperi, 2000. Avian influenza virus (H7 serotype) in a saker falcon in Italy. The Veterinary Record, 146, 740.

Marinova-Petkova, A., G. Georgiev, P. Seiler, D. Darnell, J. Franks, S. Krauss, R. J. 
Webby \& R. J. Webster, 2012. Spread of influenza virus A (H5N1) clade 2.3.2.1 to Bulgaria in common buzzards. Emerging Infectious Diseases, 18, 1596-1602.

Marinova-Petkova, A., G. Georgiev, T. Petkov, D. Darnell, J. Franks, G. Kayali, D. Walker, P. Seiler, A. Danner, A. Graham, P. McKenzie, S. Krauss, R. J. Webby \& R. G. Webster, 2016. Influenza surveillance on 'foie gras' duck farms in Bulgaria, 2008-2012. Influenza and Other Respiratory Viruses, 10, 98-108.

Munster, V. J., C. Baas, P. Lexmond, J. Waldenström, A. Wallensten, T. Fransson, G. F. Rimmelzwaan, W. E. P. Beyer, M. Schutten, B. Olsen, A. D. M. E. Osterhaus \& R. A. M. Fouchie 2007. Spatial, temporal, and species variation in prevalence of influenza A viruses in wild migratory birds. PLoS Pathogens, 3, e61.

OIE, 2015. Avian influenza (infection with avian influenza viruses). Chapter 2.3.4. In: Manual of Diagnostic Tests and Vaccines for Terrestrial Animals.

Olsen, B., V. Munster, A. Wallensten, J. Waldenström, A. Osterhaus, \& R. Fouchier, 2006. Global patterns of influenza A virus in wild birds. Science, 312, 384-388.

Roselaar, C., 2004. Fauna Europaea: Aves. In: Aves. Fauna Europaea, version 2.6.2, ed H. de Jong, https://fauna-eu.org/cdm dataportal/taxon/f2fd1555-ab1f-40f7-9cbfabebfflffbda (13 March 2019 date last accessed).

Stallknecht, D. E. \& J. D. Brown, 2016. Wild birds infections and the ecology of avian influenza viruses. In: Animal Influenza, $2^{\text {nd }}$ edn, ed. D. E. Swayne, Wiley Blackwell, Athens, Georgia, pp. 153-176.

Stallknecht, D. E. \& S. M. Shane, 1988. Host range of avian influenza virus in freeliving birds. Veterinary Research Coтmunications, 12, 125-141.

Stoimenov, G. M., 2016. Studies on influenza viruses in wild birds in Bulgaria, $\mathrm{PhD}$ thesis, University of Forestry, Sofia.

Stoimenov, G. M., G. V. Goujgoulova, B. Nikolov, R. Petrova, A. Teneva \& I.
Dimitrova, 2017a. Histopathological findings in Dalmatian pelicans (Pelecanus crispus) naturally infected with avian influenza subtype A $\mathrm{H} 5 \mathrm{~N} 1$ in Bulgaria. Journal of the Hellenic Veterinary Medical Society, 68, 369-376.

Stoimenov, G., G. Goujgoulova, G. Georgiev, B. Likov \& Y. Ivanov, 2017b. Distribution, biological and epizootiological features of highly pathogenic avian influenza of subtype H5N8 in Europe and Bulgaria in 2016/2017. Bulgarian Contact Center at the Center for Risk Assessment of the Food Chain, http://corhv.government.bg/ files $/ \% \mathrm{D} 0 \% 9 \mathrm{~A} \% \mathrm{D} 0 \% \mathrm{BD} \% \mathrm{D} 0 \% \mathrm{~B} 8 \% \mathrm{D} 0 \%$ B6\%D0\%BA\%D0\%B8/H5N8_\%D0\%BF $\% \mathrm{D} 1 \% 82 \% \mathrm{D} 0 \% \mathrm{~B} 8 \% \mathrm{D} 1 \% 87 \% \mathrm{D} 0 \% \mathrm{~B} 8 \%$ D0\%B3\%D1\%80\%D0\%B8\%D0\%BF_\%D 0\%BF\%D0\%BE_\%D0\%BF\%D1\%82\%D0 $\% \mathrm{~B} 8 \% \mathrm{D} 1 \% 86 \% \mathrm{D} 0 \% \mathrm{~B} 8 \% \mathrm{D} 1 \% 82 \% \mathrm{D} 0 \%$ B5.pdf (13 March 2019 date last accessed) (BG).

Teifke, J. P, R. Klopfleisch, A. Globig, E. Starick, B. Hoffmann, P. U. Wolf, M. Beer, T. C. Mettenleiter \& T. C. Harder, 2007. Pathology of natural infections by H5N1 highly pathogenic avian influenza virus in mute (Cygnus olor) and whooper (Cygnus cygnus) swans. Veterinary Pathology, 44, 137-143.

Van Dijk, J. G. B., R. A. M. Fouchier, \& J. H. Verhagen, 2013. Wetenschappelijk onderzoek in eendenkooien in Nederland: eenden en vogelgriepvirussen, in Blauwgoed, helen en halven: 100 jaar ringwerk in eendenkooien, eds D. Karelse \& F. Mandigers, Werkgroep Ringwerk Eendenkooien Nederland (WREN), pp. 109-120.

Verhagen, J. H., 2016. Influenza A Viruses in Migratory Birds: Ecology, evolution and the wild-domestic interface. $\mathrm{PhD}$ thesis, Erasmus University Rotterdam, Rotterdam, the Netherlands.

Webster, R. G., W. J. Bean, O. T. Gorman, T. M. Chambers \& Y. Kawaoka, 1992. Evolution and ecology of influenza A viruses. Microbiological Reviews, 56, 152-179. 
A review of wild and synantropic birds recorded as reservoirs of avian influenza viruses in Bulgaria

Zarkov, I., I. Bochev, R. Manvell \& W. Shell, 2006. Isolation of avian influenza virus in Bulgaria. The Veterinary Record, 158, 106-107.

Zarkov, I., 2008. Ecological features of influenza A virus infection in wild birds. Bulgarian Journal of Veterinary Medicine, 11, 13-20.

Paper received 02.01.2018; accepted for publication 10.05.2018

\section{Correspondence:}

Slavko N. Nikolov, PhD student Department of Internal Noninfectious Diseases,

Faculty of Veterinary Medicine; Trakia University,

Student Campus 6000 Stara Zagora, Bulgaria

e-mail: slavko92@outlook.com 